Open Access

\title{
Expeditionary energy economics (e3): the securitization of energy entrepreneurship during megacity counterinsurgencies (a NATO perspective)
}

Ion A. Iftimie(D)

Correspondence: iaiftim@gmail.com Strategic Analysis Division, NATO Energy Security Centre of Excellence, Šilo g. 5A (K-6), LT-10322 Vilnius, Lithuania

\section{Springer Open}

\begin{abstract}
The rapid urbanization around the world has generated a tremendous interest in the study of megacity insurgencies. The purpose of this paper is to introduce a new field of study - of expeditionary energy economics (e3) - that addresses energy management in the military expeditionary environment (EMMEE), particularly through the promotion of (global/ local) entrepreneurship. This study argues that successful megacity counterinsurgency (COIN) campaigns of the twenty-first century will depend on fast solutions to critical energy infrastructure (CEI) vulnerabilities within individual communities. The implementation of e3 requires that COIN practitioners have a basic understanding of community-based entrepreneurship (CBE), high-risk/high-impact innovation (HRH2l), and the CEl that these individual communities rely upon. Empirical evidence is also discussed to support a proposed e3 definition.
\end{abstract}

Keywords: Expeditionary energy economics, Megacity counterinsurgency, Energy security, Energy management in the military expeditionary environment, High-risk/high-impact innovation, Critical energy infrastructure, Community-based entrepreneurship, Energy entrepreneurship

\section{Background}

In January of 2017, another $\$ 1.4$ billion was invested to increase the supply of electricity to-and improve the reliability of-the Iraqi power infrastructure (Egan 2017), which is in the process of synchronizing with the Iranian national grid. Since 2003, over $\$ 30$ billion (Ibrahim 2014) was spent on similar national-level projects to rehabilitate the electricity sector in Iraq. Despite renovations on multiple large power stations, however, widespread power outages continue to affect most of Baghdad's communities. Reflecting on these failed investments in large power stations, Richard Haass-president of the Council on Foreign Relations-noted that "they cost a lot of money, they were all done at the top, they took a long time, and they made wonderful targets for terrorists. It would have been a lot better early on if we bought as many generators as we could and brought them over. We could have had something that could have been quickly dispersed, much less expensive, and it wouldn't have provided a target for terrorists" (Haass 2010). According to independent research, this alternative approach would

(c) The Author(s). 2018 Open Access This article is distributed under the terms of the Creative Commons Attribution 4.0 International License (http://creativecommons.org/licenses/by/4.0/), which permits unrestricted use, distribution, and reproduction in any medium, provided you give appropriate credit to the original author(s) and the source, provide a link to the Creative Commons license, and indicate if changes were made. 
have significantly reduced the annual costs-caused by electrical grid failures-of \$3-4 billion (Al-Rikabi 2017).

This article proposes that the study of energy management in the military expeditionary environment (EMMEE) is critical for future megacity counterinsurgency (COIN) deployments. In urban areas such as Baghdad-with a population of over eight million people, which is more than the five million limit established by the United Nations to qualify as a megacity (Lundqvist et al. 2005) - a successful megacity COIN campaign requires not only long-term investments in critical energy infrastructure (CEI) but also short-term results. A new field of expeditionary energy economics (e3)-the study of EMMEE-must be introduced as part of the "Maneuver, Fires and Effects" (MFE) officer formation at the lowest levels. Without understanding this applied sub-discipline of energy economics, it will be impossible to compete against insurgencies and associated entities inherent to megacity slums of the twenty-first century (e.g., the black markets and the human, organ, and drug trafficking).

\section{The role of energy security in megacity COIN strategies}

Galula-the father of counterinsurgency theory-defined an insurgency as "a protracted struggle conducted methodically, step by step, in order to attain specific intermediate objectives leading finally to the overthrow of the existing order" (Galula 1964). A COIN campaign is then "the set of political, economic, social, military, law enforcement, civil and psychological activities with the aim to defeat insurgency and address any core grievances" (AJP-3.4.4 2011). The study of economic principles during COIN or disaster relief is referred as expeditionary economics. The extant understanding of expeditionary economics treats the planning and execution of "state building" by the military as a "threelegged strategy of invasion, stabilization or pacification, and economic reconstruction," which is "the ultimate objective of counterinsurgency (COIN) campaigns" (Schramm 2010). This is in line with NATO's preferred COIN operational approach-Clear, Hold, and Build ( $\mathrm{CHB}$ - - which "encompasses offensive, defensive, stability and enabling activities" (AJP-3.4.4 2011).

The NATO doctrine states that "the effective 'offensive' operation in COIN is one that takes from the insurgent what he cannot afford to lose-control of the population. [...] Protecting the people is the mission. The conflict will be won by persuading the population, not by destroying the enemy" (McChrystal 2009). For this reason, CHB is the joint civil-military action-taken by NATO, Host Nation, and civil actors (see Fig. 1) which places the restoration of basic services and infrastructure before the neutralization of hostile groups. In the context of megacities in the twenty-first century, which are dependent on glocal (global/local) energy systems, this means that the offensive operation in COIN is dependent on EMMEE and cannot be accomplished in the absence of energy security. The US Stability joint publication articulates that "energy is clearly a priority" to achieve security during COIN (Joint Publication 3-07 2016). This implies that the implementation of quick solutions to CEI vulnerabilities takes precedence over long-term CEI development.

\section{Methods}

The aim of this study is to introduce a new field of study-of e3-that addresses EMMEE, particularly through first-hand observation and investigation. Primary research 


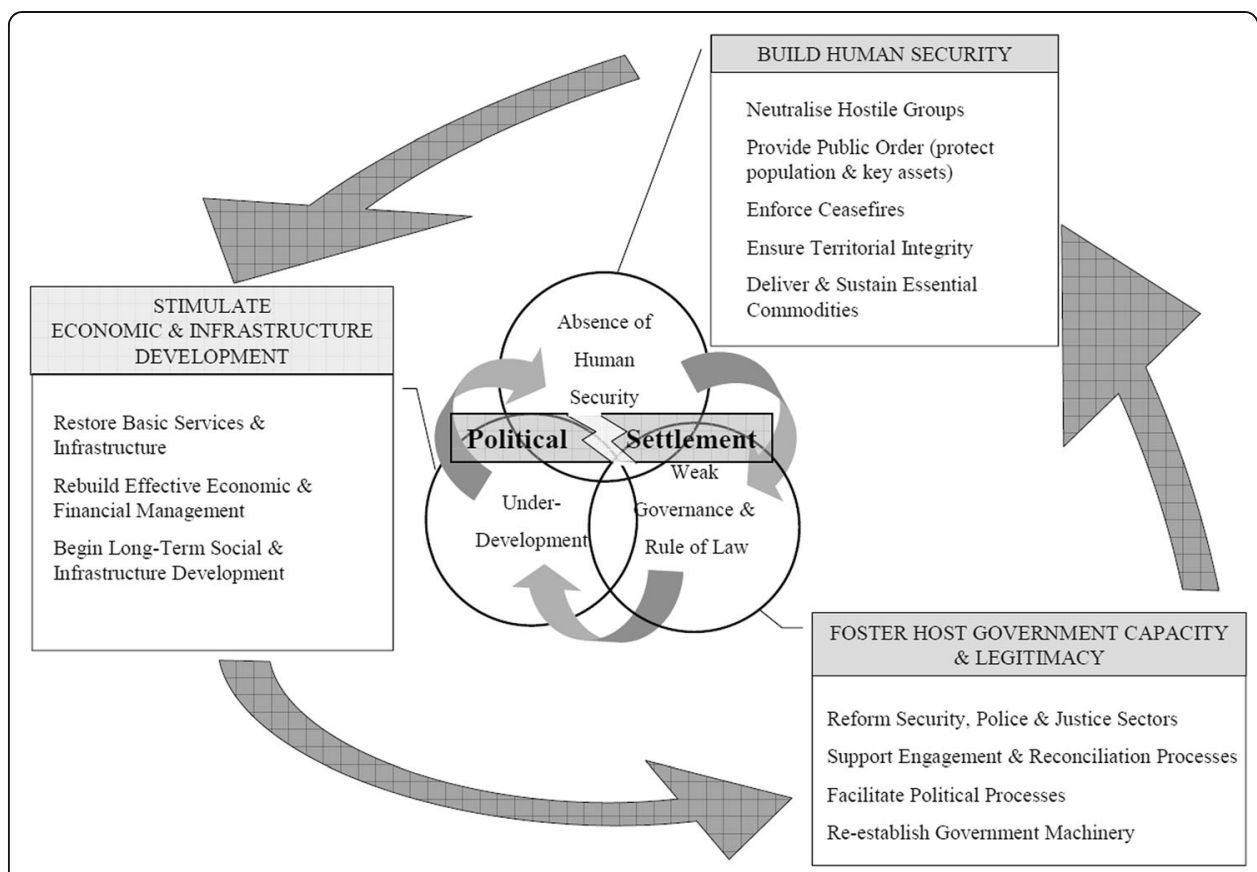

Fig. 1 Indicative activities and tasks in COIN as represented in the NATO doctrine (AJP-3.4.4 2011)

is used to illustrate that during megacity COIN, protracted/slow high-cost approaches taken independently-without practical grassroots support-will not satisfy the immediate basic needs of the population. When law and order can no longer be enforced by the legitimate government, the rapid civil-military action becomes an integral part of rebuilding CEI within the affected communities. Lieutenant General Robert L. Caslen Jr.-from his own experience in Iraq as commander of the 25th Infantry Division-recorded that "understanding the infrastructure turned out to be a key component" of successful COIN (Caslen 2010). This echoes the experience of General David H. Petraeus, as commander of the Multi-National Force-Iraq, who wrote that during COIN, soldiers "on the ground at the outset did all that they could with the resources available early on to help the people, to repair the damage done by military operations and looting, to rebuild infrastructure, and to restore basic services as quickly as possible" (Petraeus 2006). Both generals understood that "to confine Soldiers to purely military functions while urgent and vital tasks have to be done, and nobody else is available to undertake them, would be senseless" (Galula 1964).

During Global War on Terror Operations, over 3000 American soldiers have been killed or injured defending CEI (a high-risk/high-impact endeavor) (Nussbaum et al. 2016). "Maneuver, Fires and Effects" (MFE) soldiers at the lowest levels of leadershipthe strategic corporals-are an indispensable component of the glocal (global/local) EMMEE. Despite that, currently, there are no case studies explaining through unaltered, genuine information how to apply civil-military action in support of EMMEE during full-spectrum megacity COIN operations-where freedom of movement for civilian reconstruction teams is highly restricted.

\section{Expeditionary energy economics during the Iraq surge of 2007}

In January of 2007, Stryker-enabled combat teams from the Arrowhead Brigade-under the command of Colonel (now Lieutenant General) Stephen J. Townsend-were directed 
to conduct megacity COIN operations on the Haifa Street region of Baghdad. Haifa Street is a three-mile-long road in the Karkh district-downtown Baghdad, west of the Tigris River (Fig. 2)-dubbed by many military commanders that year as "the most dangerous street in Iraq." Responsibility for the clearing operation was passed to 1-14 CAV-a Stryker reconnaissance squadron commanded by Lieutenant Colonel (now Colonel) Jeffrey Peterson. Karkh district had little or no electricity since 2003. Within megacities, however, "except for transportation and some industrial and commercial process heat applications, virtually all modern economic, social, and medical services (e.g., handheld and network telecommunications infrastructure, medical equipment, water pumps, commercial and industrial equipment) are powered at the retail or local level by electricity" (Joint Publication 3-07 2016). The situation in the Karkh district was dire.

This problem was not just limited to Baghdad. Surveys conducted by D3 Systems between 2004 and 2007 indicate that, during this time frame, the Iraq population's satisfaction with the vital supply of electricity as a whole decreased despite big investments in rebuilding the national electrical infrastructure (Fig. 3). Additionally, by August of 2007, 9\% of Iraqi population believed that poor electricity supply was the single biggest problem facing their lives ( $2 \%$ more than terrorist attacks). In Baghdad, however, this lack of CEI development also provided a safe haven for the insurgency along Haifa Street.

The diagnosis of the electricity problem was simple: coalition soldiers-as a vital component of civil-military action-lacked the basic economic theoretical knowledge

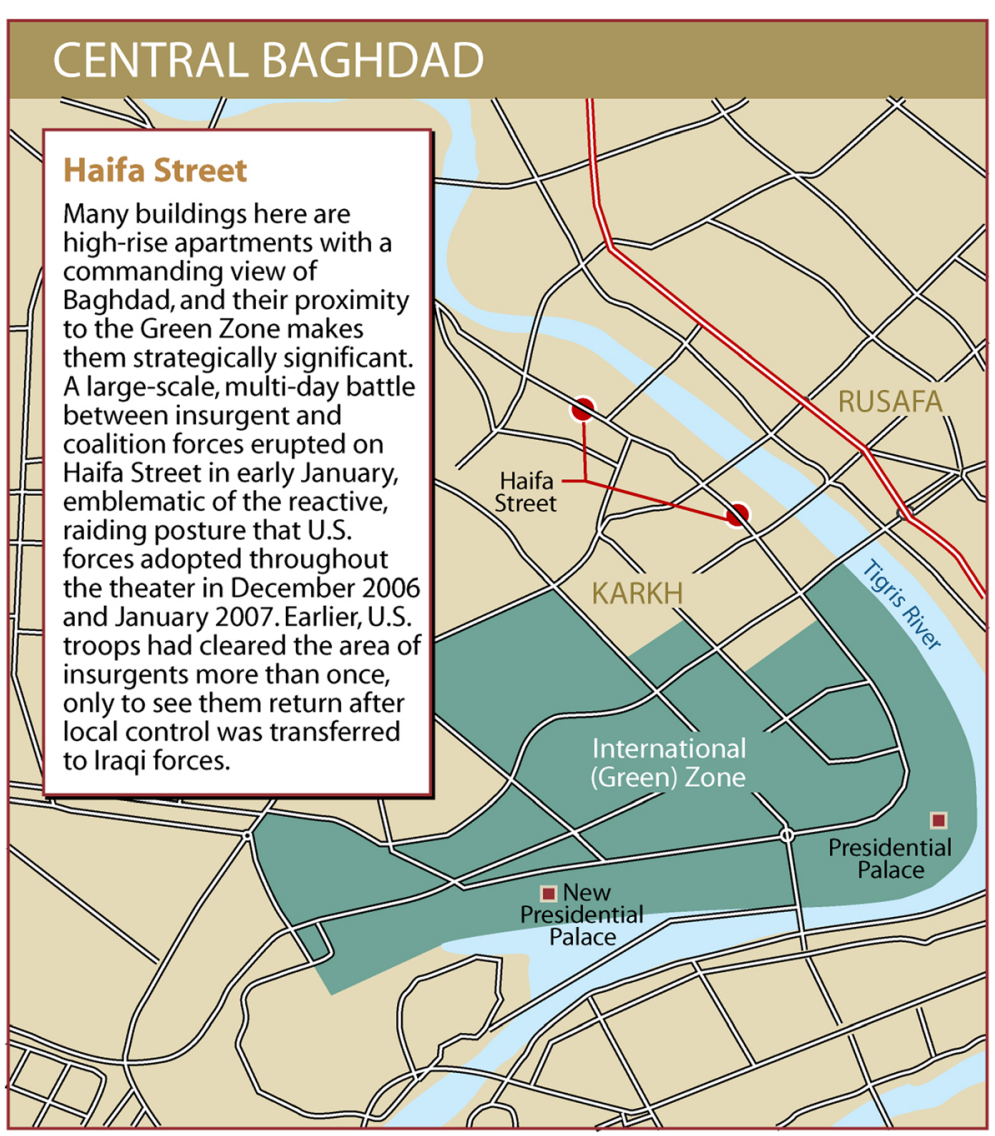

Fig. 2 Map of Karkh district (Institute for the Study of War 2008) 


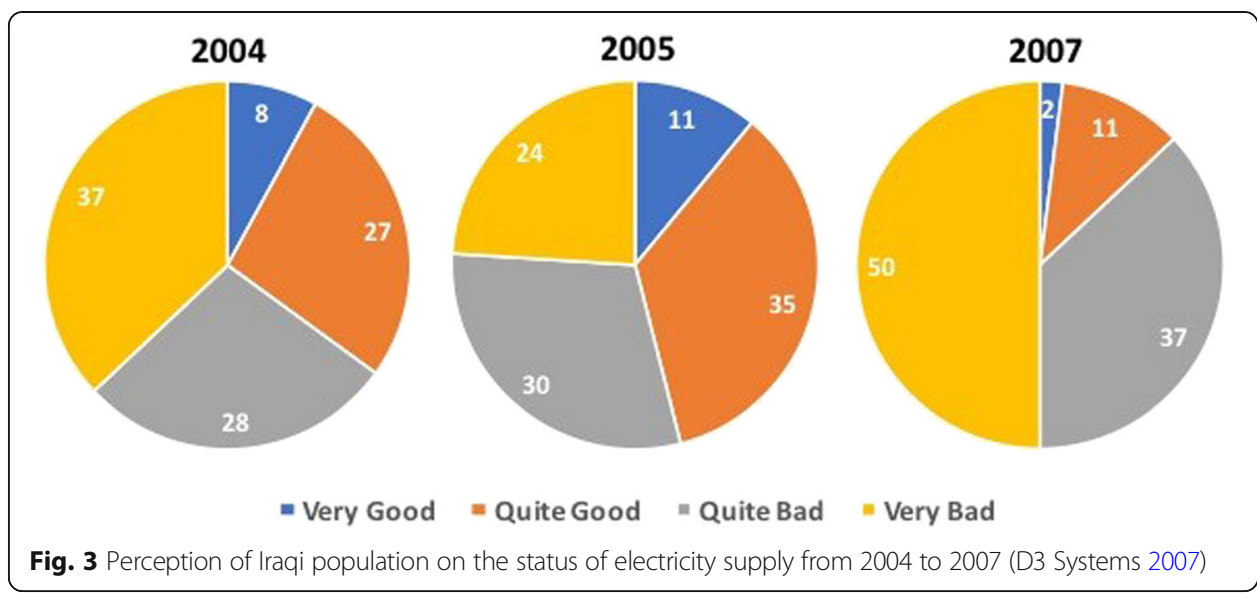

(Schramm 2010) needed to successfully restore the basic services needed for the proper functioning of society and economy. This situation changed when COL Peterson-a Professor of Economics at the West Point Military Academy and a graduate from MIT's Sloan School of Business-was ordered to conduct Clear and Hold operations along Haifa Street. During the spring and summer of 2007, the 1-14 CAV Task Force experienced first-hand the effects of poor electrical infrastructure in neglected urban communities: the dysentery deaths from drinking contaminated water and the deaths in clinics due to spoiled medications or due to antimicrobial resistance (AMR)-all connected to the lack of electricity. For the first time in his military career, LTC Peterson had to rely on his soldiers "to be entrepreneurial and to find creative ways to establish security using economic resources and economic development" (Peterson 2010). Under his leadership, the squadron's infantry and cavalry officers accidentally became hands-on students of e3, promoting community-based entrepreneurship (CBE) and high-risk/highimpact innovation (HRH2I). Not surprisingly, the D3 Systems data shows that during the period between March and September of 2007-when the electrical grid throughout Iraq continued to degrade-the supply of electricity in Baghdad slightly improved (Fig. 4). While the change in perceptions was small, glocal (global/local) CEI improvements within Karkh district significantly contributed to this change in trends. For the first time, there is evidence to correlate the application of EMMEE with positive behavioral changes within the local communities.

\section{Haifa street: a red-light district without lights}

In 2004, COL Peterson came across an essay in foreign affairs on building entrepreneurial economies. In it, Carl J. Schramm-American economist and former professor of finance and policy at the Johns Hopkins University-wrote that going forward, support for entrepreneurship will be vital to the successful development of the economy (Schramm 2004). Briefly, after the US President announced-in January of 2007-his "New Way Forward," COL Peterson and his reconnaissance squadron were ordered "to secure and protect critical areas of Baghdad" (Kagan 2007). Within 6 months, his troops proved that the civil-military action can successfully apply the CBE \& HRH2I concepts during COIN operations, significantly contributing to the overwhelming success of the surge. 


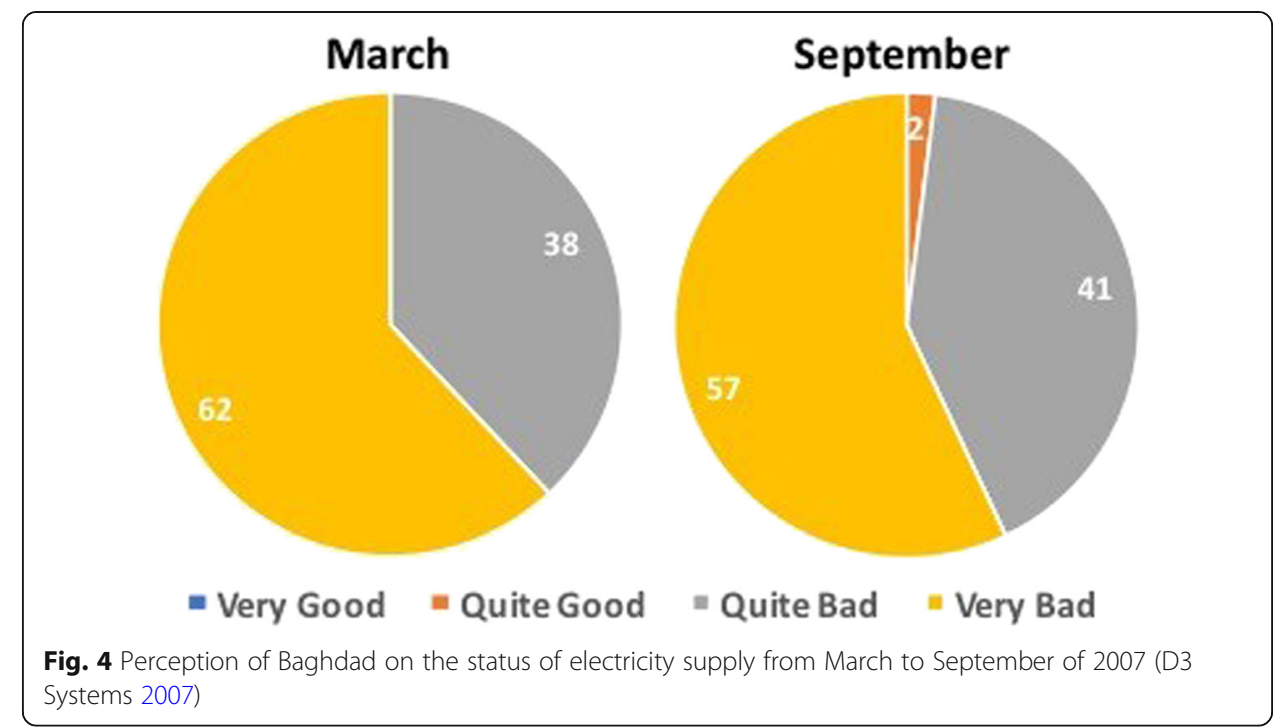

The following study focuses on the re-establishment of electricity infrastructurethrough CBE \& HRH2I-in the Karkh neighborhood of Salhia, the heart of Baghdad's red-light district under the Ba'athist rule. West of the Tigris River and right next to the British Embassy, the Salhia neighborhood was home to the Iraqi National Museum, the Iraqi Theatre Centre, hotels, coffee houses, and brothels. Between 2003 and the infamous Battle of Haifa Street in early 2007, however, it suffered brutal sectarian killings and atrocities. The Iraqi National Museum made constant international headlines, the theater center closed its doors after repeated suicide bomb attacks, and all the hotels were now housing refugees from around Iraq.

The infantry platoon assigned to conduct Clear and Hold operations in the Salhia neighborhood spent the first days on the ground asking local families to fill out surveys about the type of essential services they required and the immediate needs of the community. The answer surprised the military leadership, with the biggest problems being identified as the lack of fuel and electricity (Fig. 5). The neighborhood consisted of 1900 families, primarily lower class within the neighborhood and middle to upper

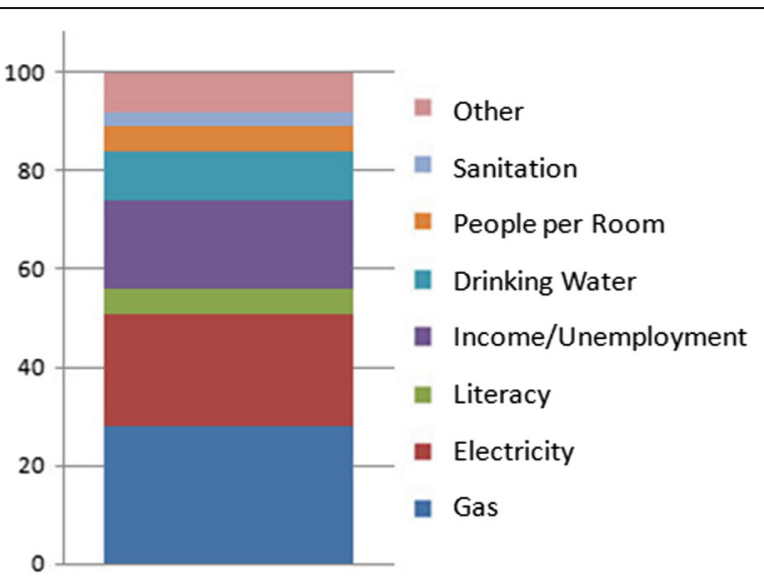

Fig. 5 1-14 CAV Task Force surveys showing main needs of the population in the Salhia neighborhood (2007) 
class along the Haifa Street apartments. Unemployment was about $60 \%$, and average income per household was under $\$ 800$ per year. Eighty percent of the population was living in poverty; $32 \%$ were living in extreme poverty and were dependent on aid. Sixty-five percent of the people formally engaged in the process of production were engaged in furniture manufacturing, where their economic potential was limited by the rudimentary means of production. This chaotic and fragile structure, where most workshops resembled those of the early Middle Ages, was profoundly unstable and could not meet the multidimensional needs of the community. Locally, investment in more performant tools was seen as unprofitable due to the unreliability of electricity and fuel delivery.

What helped the infantry platoon gain-between March and September of 2007significant human terrain was the rebuilding of local municipal and government infrastructure by redirecting the civil-military focus toward community-based entrepreneurship. The model that COL Peterson adopted [SWEAT-MSFGE] called for civil-military actionsby, with, and through the local Neighborhood Advisory Councils (NAC)-encouraging local innovation and entrepreneurship toward renovated Sewer systems, cleaner Water, more Electricity, improved Academic institutions, less Trash, better Medical facilities, more Security, more Fuel, better Governance, and better management of Economics. This model was also adopted in the US Stability joint publication 3-07, which states that the "basic function of local governance is often lost during conflict and other disasters; efforts to restore governance, particularly at the local level, should focus on essential servicesgenerally referred to as SWEAT-MSO [sewage, water, electricity, academics, trash, medical, security, and other considerations]" (Joint Publication 3-07 2016). The joint publication, however, overlooked the value of CBE \& HRH2I-that COL Peterson promoted-in combating insurgencies.

\section{Discussion}

Along the entire Haifa Street, control over the socioeconomic structure at local levels lay in the hands of insurgents and the black market; they also controlled access to the two biggest needs of the urban community: fuel and electricity. While 1-14 CAV could temporarily become the guarantor of security, it could not guarantee the uninterrupted supply of fuels and electricity into the community. Even if new generators were brought in the community, without fuel they would not run, schools would be dark, businesses would not flourish, water pumps would not work, and sewer facilities would not run. Fuel and electricity shortages denied the Salhia neighborhood a chance to advance beyond primitive economic stages. In the absence of a highly mechanized and automated economy, the local population had to find work outside the bounds of traditional institutions of employment-sometime even facilitating terrorism and the local insurgencies.

In the absence of more efficient energy sources, six broken $150 \mathrm{kV}$ generators were identified within the vicinity of critical infrastructures. Their owners-Abbas, Yusif, Amid, Kaleb, Munthel, and Mokdam - had no entrepreneurship training but were open to work with the NAC and the infantry platoon to supply the neighborhood with electricity. With the assistance of the infantry platoon, the six generator owners, the two electricians, and the five accountants set the parameters of the electrical grid: each household attached to the grid agreed to pay a monthly fee in exchange for $3 \mathrm{~h}$ of electricity during the day and $3 \mathrm{~h}$ during the night, limiting lighting points per house 
to four lamps and a socket for one energy-efficient appliance (radio, TV, or even an indoor portable fan). To ensure availability of resources to all, load limiters were installed for each line pulled from the generator. A schematic design of the electricity generation, transmission, and distribution network for the area was generated and, shortly afterwards, implemented.

With generators and maintenance in place, access to fuel still remained a major issue (as its glocal transportation remained under the control of the black market). A solution was not found for the fuel shortage until June, when "Jamal"-a powerful Baghdad politician-reached a mutually beneficial agreement with the the NAC to insure the flow of fuel straight from the Ministry of Oil. By mid-July, Abbas alone was distributing power to over 120 households and was able to reap a net profit of almost \$1000 a month. With civil-military assistance, Yusif, Amid, Kaleb, Munthel, and Mokdam developed similar electricity supply grids, and one generator owner, Munthel, received a Coalition Forces micro-grant for generator maintenance and the purchase of a new generator. By September of 2007, over 500 households and 24+ shops that did not have access to electricity since 2003 could now enjoy it (Fig. 6).

The Haifa Street case study during the Surge of 2007 is a clear illustration of how CBE \& HRH2I with the assistance of civil-military actions can help in the CEI rehabilitation efforts during megacity COIN Clear and Hold operations-where the freedom of movement for civilian reconstruction teams is highly restricted. This model was soon adopted throughout Karkh, and by 2008, with all the CEI security and operation, Haifa Street, "once one of the most dangerous places in Baghdad, was bustling with commerce" (Bowen 2008). The process of protecting and restoring CEI, however, would not have been possible without the ultimate sacrifice of 48 warriors of the Arrowhead Brigade. At the end of the deployment, the soldiers of the Arrowhead Brigade were credited with "saving and changing the lives of Iraqi people" (SENATE RESOLUTION 8709 2008).

\section{Conclusion}

In a century marked by rapid urbanization across the world (Fig. 7), EMMEE is no longer possible in the absence of electricity-which is why e3 should be an essential consideration of every megacity COIN and disaster recovery planning. This change in

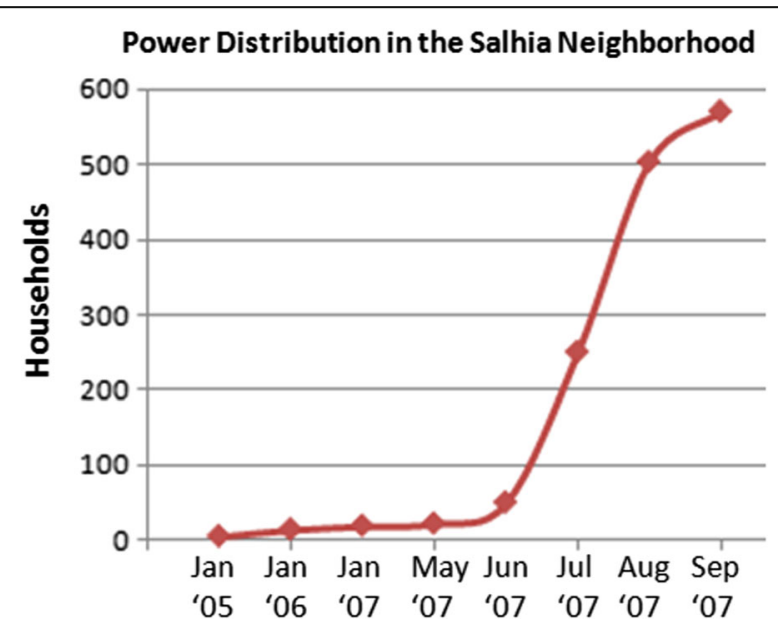

Fig. 6 Access to electricity by household in the Salhia neighborhood (2007) 


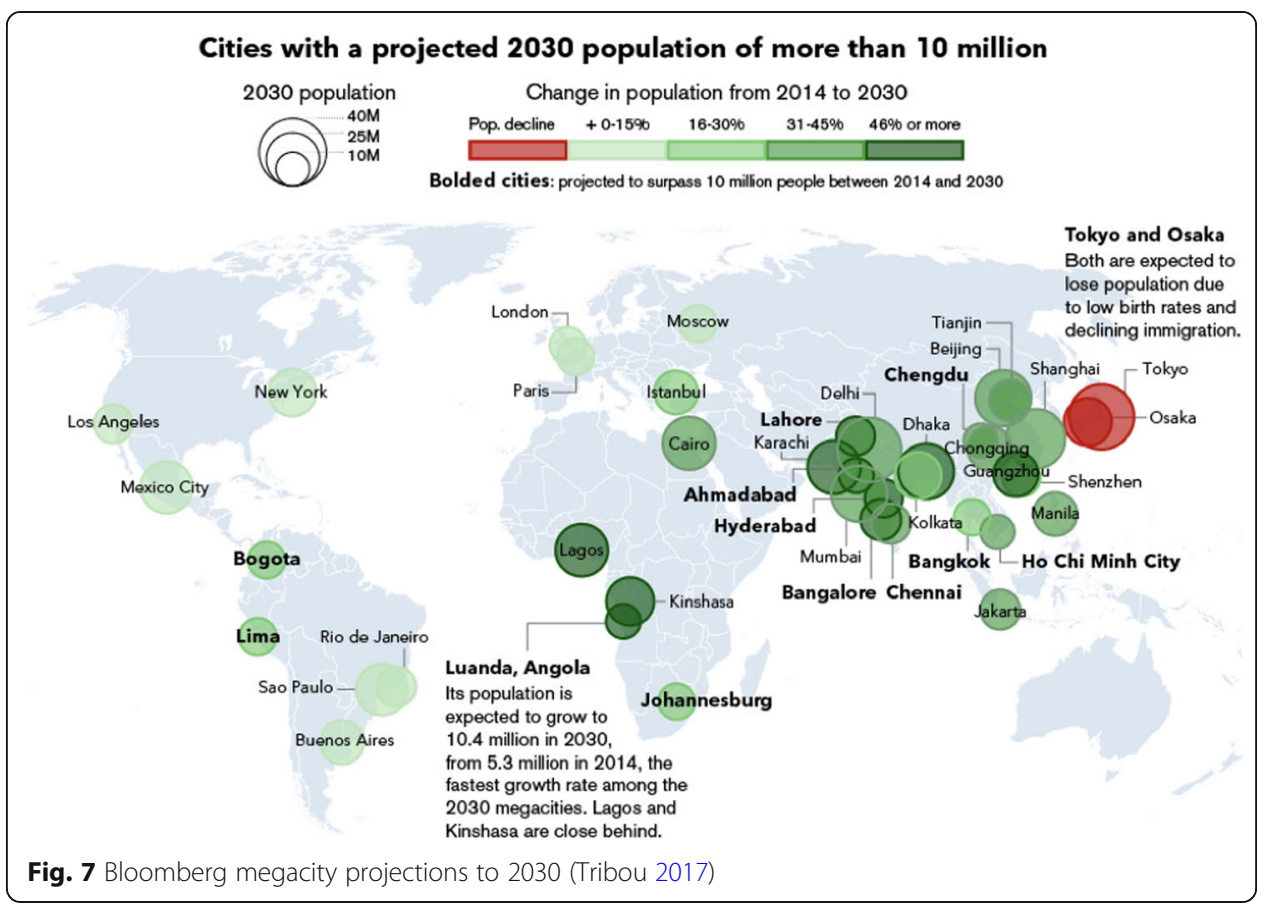

urban demographics also concerned US Secretary of State Colin Powell when he warned the US President that the invasion "isn't just a simple matter of going to Baghdad," but about "what happens after," when the military becomes responsible of rebuilding the CEI. "If you break it, you own it," Secretary Powell famously argued (Breslow 2016). After over one decade of war and tens of billions of dollars spent on reconstruction of national-level CEI in Iraq, the unreliability of the grid continues to force individual communities to rely on diesel generators as the primary sources of electricity (Egan 2017). This underscores the need for military commanders to pay more attention to $\mathrm{e} 3$ in the planning of future megacity COIN campaigns.

The successful implementation of e3 requires that COIN practitioners have a basic understanding of CEI. On Haifa Street, before the 2007 surge, the unreliability of CEI created a safe haven and power base for insurgents. During the surge, however, the effect of civil-military units promoting CBE $\mathcal{E} H R H 2 I$ as a solution to local energy supply shortages on Haifa Street was a significant increase in the standard of living (with increased support for the Coalition Forces). The Haifa Street case study shows that one of the most vital elements of successful megacity COIN is facilitating rapid access of the urban community to affordable and reliable energy sources-which is a matter of managing both security of CEI and security of supply.

\section{Acknowledgements}

I am particularly grateful for the assistance given by Colonel Jean-Marc Bouillet, Deputy Director of the NATO ENSEC $\mathrm{COE}$, and by Dr. Elias G. Carayannis, Full Professor of Science, Technology, Innovation, and Entrepreneurship at the School of Business of the George Washington University in Washington, D.C.

Funding

No funds were provided to conduct this research. 
Author's contributions

The author read and approved the final manuscript.

\section{Author's information}

MAJ (USA) Ion Iftimie is a research fellow within the Strategic Analysis Department of the NATO Energy Security Centre of Excellence in Vilnius, Lithuania. He is also a Doctoral Candidate in Energy Security at the Central European University in Budapest, Hungary. During the Iraqi Surge of 2007, MAJ (USA) Ion Iftimie conducted over 113 combat missions as commander of a rifle platoon-attached to 1-14 CAV, a Stryker reconnaissance squadron in the Arrowhead Brigade_-on the Haifa Street of Baghdad. This article is a first-hand account on how General David Petraeus skillfully orchestrated stability operations during the surge of 2007 in Iraq.

\section{Competing interests}

The author declares no competing interests.

\section{Publisher's Note}

Springer Nature remains neutral with regard to jurisdictional claims in published maps and institutional affiliations.

Received: 8 March 2018 Accepted: 26 March 2018

Published online: 11 April 2018

\section{References}

AJP-3.4.4 (2011). Allied joint doctrine for counterinsurgency (COIN). Brussels: North Atlantic Treaty Organization. NATO Standardization Agency (NSA).

Al-Rikabi, H. (2017). An assessment of electricity sector reforms in Iraq. Al Bayan Center for Planning and Studies. http:// www.bayancenter.org/en/2017/09/1264. Accessed 31 Oct 2017.

Bowen, S (2008). Quarterly report to the United States Congress. Special Inspector General for Iraq Reconstruction. Arlington: https://cybercemetery.unt.edu/archive/sigir/20131001092117/http://www.sigir.mil/files/quarterlyreports/ October2008/Report_-_October_2008.pdf\#view=fit. Accessed 17 Nov 2017.

Breslow, H.M. (2016). Colin Powell: U.N. Speech "Was a Great Intelligence Failure". http://www.pbs.org/wgbh/frontline/ article/colin-powell-u-n-speech-was-a-great-intelligence-failure. Accessed 17 Nov 2017.

Caslen, R (2010). Summary of the summit on entrepreneurship and expeditionary economics. Kansas City: Ewing Marion Kauffman Foundation http://www.cgscfoundation.org/wp-content/uploads/2011/01/EEESpecial-Report.pdf. Accessed 17 Nov 2017

D3 Systems. (2007). Iraq Polls: In graphics. BBC News. http://news.bbc.co.uk/2/hi/middle_east/6451841.stm; http://news. bbc.co.uk/2/hi/middle_east/6983027.stm. Accessed 17 Nov 2017.

Egan, M. (2017). GE power: New \$1.4 billion GE power deal will supply Iraq with reliable electricity. https://www.ge com/reports/new-1-4-billion-ge-deal-will-supply-iraq-reliable-power. Accessed 31 Oct 2017.

Galula, D. (1964). Counterinsurgency warfare: Theory and practice

Haass, R (2010). Summary of the summit on entrepreneurship and expeditionary economics. Kansas City: Ewing Marion Kauffman Foundation http://www.cgscfoundation.org/wp-content/uploads/2011/01/EEESpecial-Report.pdf. Accessed 17 Nov 2017.

Ibrahim, H. (2014). Iraq to allocate USD4.7bn for electricity sector in 2014. Zawya. http://bilateralchamber.org/iraqallocate-usd4-7bn-electricity-sector-2014. Accessed 31 Oct 2017.

Institute for the Study of War. (2008). The significance of Haifa Street in Baghdad. http://www.understandingwar.org/ sites/default/files/HaifaStreet_.jpg. Accessed 17 Nov 2017.

Joint Publication 3-07. (2016). Chairman of the Joint Chiefs of Staff (CJCS). http://www.dtic.mil/doctrine/new_pubs/jp3_07.pdf. Accessed 17 Nov 2017.

Kagan, FW (2007). Iraq: A turning point. AEl http://www.aei.org/events/iraq-a-turning-point/print. Accessed 31 Oct 2017.

Lundqvist, J., Tortajada, C., Varis, O., Biswas, A. (2005). Water management in megacities. Ambio, volume 34, $3267-268$. Royal Swedish Academy of Sciences: Stockholm

McChrystal, SA (2009). ISAF commander's counterinsurgency quidance. Kabul: Headquarters International Security Assistance Force http://www.nato.int/isaf/docu/official_texts/counterinsurgency_guidance.pdf. Accessed 30 Oct 2017.

Nussbaum, D, Pickl, S, Dupuy, A, Marian, SN (2016). The nexus between cyber security and energy security. Proceedings of the 15th European Conference on Cyber Warfare and Security (ECCWS 2016). Munich: Hosted by the University of Bundeswehr.

Peterson, J (2010). Summary of the summit on entrepreneurship and expeditionary economics. Kansas City: Ewing Marion Kauffman Foundation http://www.cgscfoundation.org/wp-content/uploads/2011/01/EEESpecial-Report.pdf. Accessed 17 Nov 2017.

Petraeus, D. (2006). Learning counterinsurgency: Observations from soldiering in Iraq. Military Review LXXXVI, 2. http:// www.au.af.mil/au/awc/awcgate/milreview/petraeus1.pdf. Accessed 17 Nov 2017.

Schramm, CJ. (2004). Building entrepreneurial economies. Foreign Affairs https://www.foreignaffairs.com/articles/200407-01/building-entrepreneurial-economies. Accessed 17 Nov 2017.

Schramm, CJ. (2010). Expeditionary economics: Spurring growth after conflicts and disasters. Foreign Affairs, 89(3), 89-99.

Senate Resolution 8709. (2008). Washington State

Tribou, A. Bloomberg visual data. Source: United Nations World Urbanization Prospects. https://www.bloomberg.com/ graphics/infographics/global-megacities-by-2030.html. Accessed on 27 November 2017 